Article

\title{
Improved Membrane Inlet Mass Spectrometer Method for Measuring Dissolved Methane Concentration and Methane Production Rate in a Large Shallow Lake
}

\author{
Feng Zhao ${ }^{1,2}$, Hai Xu ${ }^{1, *}$, Todd Kana ${ }^{3}$, Guangwei Zhu ${ }^{1}$, Xu Zhan ${ }^{2}$, Wei Zou ${ }^{1}$, Mengyuan Zhu ${ }^{1}$, Lijuan Kang ${ }^{1}$ \\ and Xingchen Zhao ${ }^{1}$ \\ 1 State Key Laboratory of Lake and Environment, Nanjing Institute of Geography and Limnology, \\ Chinese Academy of Sciences, Nanjing 210008, China; 6181402037@stu.jiangnan.edu.cn (F.Z.); \\ gwzhu@niglas.ac.cn (G.Z.); wzou@niglas.ac.cn (W.Z.); myzhu@niglas.ac.cn (M.Z.); \\ kanglijuan18@mails.ucas.ac.cn (L.K.); zhaoxingchen19@mails.ucas.ac.cn (X.Z.) \\ 2 School of Environment and Civil Engineering, Jiangnan University, Wuxi 214122, China; \\ xuzhan@jiangnan.edu.cn \\ 3 Horn Point Laboratory, University of Maryland Center for Environmental Science, P.O. Box 775, \\ Cambridge, MD 21613, USA; kana@bayinstruments.com \\ * Correspondence: hxu@niglas.ac.cn; Tel.: +86-25-86882186; Fax: +86-25-57714759
}

check for updates

Citation: Zhao, F.; Xu, H.; Kana, T.; Zhu, G.; Zhan, X.; Zou, W.; Zhu, M.; Kang, L.; Zhao, X. Improved

Membrane Inlet Mass Spectrometer Method for Measuring Dissolved Methane Concentration and Methane Production Rate in a Large Shallow Lake. Water 2021, 13, 2699. https:/ / doi.org/10.3390/w13192699

Academic Editor: Qilin Wang

Received: 23 July 2021

Accepted: 23 September 2021

Published: 29 September 2021

Publisher's Note: MDPI stays neutral with regard to jurisdictional claims in published maps and institutional affiliations.

Copyright: (c) 2021 by the authors. Licensee MDPI, Basel, Switzerland. This article is an open access article distributed under the terms and conditions of the Creative Commons Attribution (CC BY) license (https:/ / creativecommons.org/licenses/by/ $4.0 /)$.

\begin{abstract}
Natural water bodies, such as lakes, rivers, and oceans, are important sources of atmospheric methane $\left(\mathrm{CH}_{4}\right)$. Therefore, quantitative and accurate determination of the dissolved $\mathrm{CH}_{4}$ concentration in water is of great significance for studying $\mathrm{CH}_{4}$ emissions and providing an in-depth understanding of the carbon cycle. Headspace gas chromatography (HGC) is the traditional method for measuring $\mathrm{CH}_{4}$ in water. Despite its long success, it has a lot of problems in use, such as complex pretreatment and a long measurement time, and it is not suitable for the $\mathrm{CH}_{4}$ determination of a large number of samples. In view of these shortcomings, a more convenient and efficient method based on membrane inlet mass spectrometry (MIMS) for quantitative measurements of the dissolved $\mathrm{CH}_{4}$ concentration in water was established. In our study, the standard curves showed that the method had high accuracy, both at low and high $\mathrm{CH}_{4}$ concentrations. After a laboratory test, to evaluate the sensitivity of this method, samples were collected from a large shallow lake (Lake Taihu). Both the HGC method and MIMS method were used to determine the dissolved $\mathrm{CH}_{4}$ to compare these two methods. The small difference in $\mathrm{CH}_{4}$ concentration obtained from the MIMS and HGC methods and the significant correlation between the $\mathrm{CH}_{4}$ concentrations derived from the MIMS method with those derived from the HGC method showed that the MIMS method could replace the HGC method in the determination of dissolved $\mathrm{CH}_{4}$ in natural waters. In addition, we also measured the sediment $\mathrm{CH}_{4}$ production rates in three different areas of Lake Taihu using a laboratory incubation experiment. During the experiment, significant $\mathrm{CH}_{4}$ accumulations were observed, indicating that sediment $\mathrm{CH}_{4}$ production was an important source of dissolved $\mathrm{CH}_{4}$ in the water column. Our study concluded that the MIMS method was sufficient and a better alternative than the HGC method owing to its capacity to measure a broad range of values plus the fact that it was relatively easy to use with less manipulation of the samples.
\end{abstract}

Keywords: membrane inlet mass spectrometer; dissolved methane; headspace gas chromatography; methane production rate

\section{Introduction}

Greenhouse gases mainly include methane $\left(\mathrm{CH}_{4}\right)$, carbon dioxide, and nitrous oxide, which can lead to the greenhouse effect, which is having a significant impact on the natural ecosystem, such as climate anomalies, melting glaciers, and increasing sea levels [1-4]. Although the $\mathrm{CH}_{4}$ concentration in the atmosphere is very low compared with carbon dioxide, the greenhouse effect of $\mathrm{CH}_{4}$ is more than 21-23 times that of carbon dioxide [5]. 
As important sources of $\mathrm{CH}_{4}$, natural water bodies, such as lakes, oceans, and reservoirs, have attracted much attention [6,7]. Therefore, there is a great demand for determining the dissolved $\mathrm{CH}_{4}$ concentrations in waters. Although the concentration of $\mathrm{CH}_{4}$ in waters cannot be used to directly quantify the $\mathrm{CH}_{4}$ emissions to the atmosphere, it can reveal the potential of $\mathrm{CH}_{4}$ diffusion from waters to the atmosphere. In addition, the $\mathrm{CH}_{4}$ diffusive flux can be calculated through Fick's first law if we know the dissolved $\mathrm{CH}_{4}$ concentration, corresponding water temperature, salinity, and wind speed $[7,8]$, which indicates that if we can quickly and accurately determine the concentration of the dissolved $\mathrm{CH}_{4}$, it seems to be simpler and more convenient to calculate the $\mathrm{CH}_{4}$ diffusion from natural waters. Meanwhile, an accurate and effective method for the determination of dissolved $\mathrm{CH}_{4}$ can help us to estimate the $\mathrm{CH}_{4}$ production or oxidation capacity in waters, which is of great significance to the study of the fate of $\mathrm{CH}_{4}$.

Traditionally, the main method for the determination of $\mathrm{CH}_{4}$ in water is headspace gas chromatography (HGC), which requires complex pretreatment [9]. The HGC method is widely used in the determination of $\mathrm{CH}_{4}$ and nitrous oxide in natural water bodies [10,11], but this method cannot directly measure the concentration of dissolved $\mathrm{CH}_{4}$ in waters, resulting in low efficiency. Thus, a more convenient and efficient method is desired. Although $\mathrm{CH}_{4}$ measurements using MIMS go back to the 1980s [12], this technique has not been generally used for environmental water sample measurements. As a relatively new method in environmental science for measuring dissolved gases in water, membrane inlet mass spectrometry (MIMS) has attracted much attention owing to its high precision, convenience, and efficiency. MIMS instruments can be configured with a variety of membrane interfaces, including probes, flat membranes in chambers, and flow-through tube membranes [13]. Using a tube membrane with a highly stable flow and temperature control results in highly stable signals with very high precision of gas ratios (better than 1 per mil). This form of MIMS has become the standard for measuring the $\mathrm{N}_{2}$ / Ar ratio and ${ }^{15} \mathrm{~N}$ in denitrification studies, which require very high precision measurements [14]. MIMS has had limited use for measuring $\mathrm{CH}_{4}$ in environmental samples and the vast majority of aquatic $\mathrm{CH}_{4}$ studies utilize alternative methods, such as gas chromatography (GC). Given the high precision and convenience of MIMS for measuring dissolved air gases using the standard methods for denitrification $[15,16]$, we evaluated this analytical approach for $\mathrm{CH}_{4}$ detection in lake water samples. A recent study used the MIMS method to measure the $\mathrm{CH}_{4}$ concentration in culture experiments by using the ratio relative to $\mathrm{Ar}\left(\mathrm{CH}_{4}\right.$ : $\mathrm{Ar}$ ratio) [17]. However, this calculation method has a great problem in that the Ar determination using the MIMS method can be greatly affected by the $\mathrm{O}_{2}$ concentration [18]. Here, we used the standard curve method to accurately calculate the dissolved $\mathrm{CH}_{4}$ concentration based on the MIMS method.

With the considerations mentioned above, we tested the reliability of the MIMS method for measuring the $\mathrm{CH}_{4}$ concentration in the laboratory. Furthermore, we also sampled water samples from a large shallow lake, namely, Lake Taihu, to verify that this method is also suitable for dissolved $\mathrm{CH}_{4}$ concentration measurement in natural waters. Sediment cores were also collected from Lake Taihu to quantify the sediment $\mathrm{CH}_{4}$ production rate to show that this method is appliable in culture experiments.

\section{Materials and Methods}

\section{1. $\mathrm{CH}_{4}$ Measurement Approach Using MIMS}

MIMS uses a sampling probe or water sampler equipped with a gas-permeable membrane that separates the water sample from the vacuum of the mass spectrometer. The MIMS in this study (Bay Instruments) includes a tube membrane inside the vacuum inlet (Figure 1). Water samples are pumped through stainless steel tubing in a thermostated bath $\left(20^{\circ} \mathrm{C}\right)$ prior to entering the vacuum inlet where the membrane tube resides. The flux of dissolved gases across the membrane depends on the flow velocity and temperature and these parameters were held constant. All samples were measured at $20^{\circ} \mathrm{C}$. The gas stream was dried using a liquid nitrogen U-tube trap prior to entering the mass spectrometer. 
The instrument signals were assessed for stability by pumping temperature-controlled $\left( \pm 0.02{ }^{\circ} \mathrm{C}\right)$ water through the membrane [14].

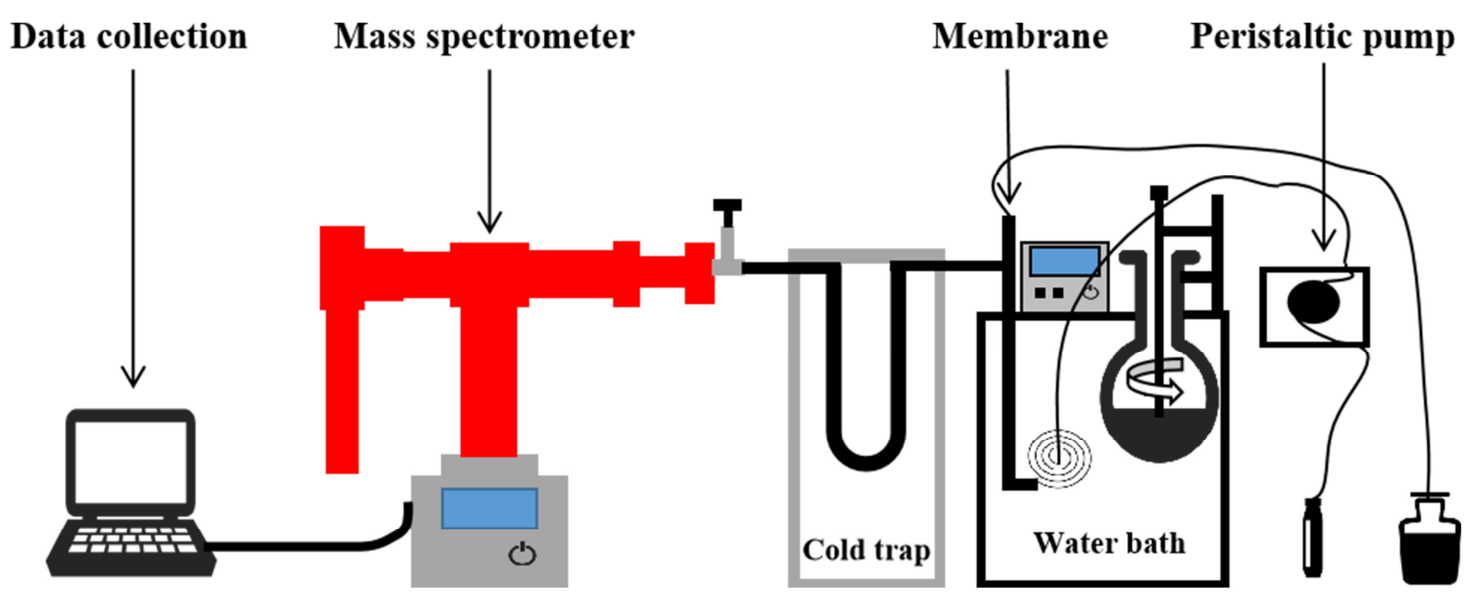

Figure 1. The diagram of the MIMS system.

\subsubsection{Preparation of Standard Samples}

$\mathrm{CH}_{4}$ standard samples were prepared using a headspace equilibrium method. A pressurized container containing $99.99 \% \mathrm{CH}_{4}$, a sealed gas collecting bag, and a quantitative syringe were used to transfer $\mathrm{CH}_{4}$ to $12 \mathrm{~mL}$ Labco Exetainer vials. Before the addition, the vial volume was calibrated by weighing the water of a filled vial. After calibration, $7 \mathrm{~mL}$ of deionized water was added, leaving a $5 \mathrm{~mL}$ headspace. A known amount of $\mathrm{CH}_{4}$ was injected into the headspace through a quantitative gas-tight syringe. The vials were shaken for $5 \mathrm{~min}$ or more and then were put into a thermostatic water bath for solubility equilibration.

\subsubsection{Measurement of Standard Samples}

$\mathrm{CH}_{4}$ was conventionally measured with MIMS using mass 15 , which was the $\mathrm{CH}_{3}{ }^{+}$ fragment of $\mathrm{CH}_{4}$, avoiding the pronounced and variable mass 16 peak that is associated with $\mathrm{O}^{+}$. This fragment was $90 \%$ of the intensity of the mass 16 peak of $\mathrm{CH}_{4}$ and sat on a low baseline peak. For nanomolar and low micromolar concentrations, it was necessary to use the secondary electron multiplier (SEM) detector.

\subsubsection{Calculation of Dissolved $\mathrm{CH}_{4}$ in Standard Samples}

The concentration of dissolved $\mathrm{CH}_{4}$ in standard samples was calculated according to Henry's law and Dalton's law. Henry's law was put forward by William Henry in 1803. It was applicable to the situation that there was no chemical reaction in the system and the temperature was constant. In this case, Henry's law states that the concentration of the gas dissolved in the liquid would be proportional to the partial pressure of the gas in the gaseous phase. Dalton's law states that for a gas mixture without a chemical reaction, the total pressure is equal to the sum of the partial pressures of all gases in the mixture. The specific formulas were as follows:

$$
\begin{gathered}
\mathrm{C}_{\text {water }}^{\mathrm{CH}_{4}}=\mathrm{P}_{\mathrm{CH}_{4}} \times \mathrm{H} \\
\mathrm{H}=\beta / \mathrm{V}_{\mathrm{m}} \\
\ln (\beta)=\mathrm{A}_{1}+\mathrm{A}_{2} \times 100 / \mathrm{T}+\mathrm{A}_{3} \times \ln (\mathrm{T} / 100)+\mathrm{S} \times\left[\mathrm{B}_{1}+\mathrm{B}_{2} \times \mathrm{T} / 100+\mathrm{B}_{3} \times(\mathrm{T} / 100)^{2}\right]
\end{gathered}
$$


where $\mathrm{H}$ is the solubility coefficient of $\mathrm{CH}_{4}\left(\mathrm{~mol}(\mathrm{~L} \mathrm{~atm})^{-1}\right), \mathrm{C}_{\text {water }}^{\mathrm{CH}_{4}}$ is the $\mathrm{CH}_{4}$ concentration in water $\left(\mathrm{mol} \mathrm{L}^{-1}\right), \mathrm{P}_{\mathrm{CH}_{4}}$ is the partial pressure of $\mathrm{CH}_{4}$ in the headspace after reaching equilibrium. $\beta$ is Benson's solubility coefficient. $A_{1}, A_{2}, A_{3}, B_{1}, B_{2}$, and $B_{3}$ are constants and can be derived from previous studies [19]. $\mathrm{S}$ is the salinity of the solution (\%). $\mathrm{T}$ represents the water temperature $(\mathrm{K}) . \mathrm{V}_{\mathrm{m}}$ is the molar volume.

$$
\begin{gathered}
\mathrm{P}_{\mathrm{CH}_{4}}=\frac{\mathrm{V}_{\mathrm{HS}}^{\mathrm{CH}_{4}}}{\mathrm{~V}_{\mathrm{HS}}} \times \mathrm{P}_{\text {tot }} \\
\mathrm{P}_{\text {tot }}=\frac{\mathrm{V}_{\mathrm{inj}}^{\mathrm{CH}_{4}}+\mathrm{V}_{\mathrm{HS}}}{\mathrm{V}_{\mathrm{HS}}} \times \mathrm{P}
\end{gathered}
$$

where $\mathrm{V}_{\mathrm{HS}}^{\mathrm{CH}_{4}}$ is the volume of $\mathrm{CH}_{4}$ in the headspace after reaching equilibrium (L), VHS is the volume of headspace in the vial $(\mathrm{L}), \mathrm{P}_{\text {tot }}$ is the total pressure in the vial, $\mathrm{P}$ is the standard atmospheric pressure at $20{ }^{\circ} \mathrm{C}$, and $\mathrm{V}_{\mathrm{inj}}^{\mathrm{CH}_{4}}$ is the volume of the injection (L). Because the solubility of $\mathrm{CH}_{4}$ is very low, changes in the total pressure due to the dissolution of $\mathrm{CH}_{4}$ were ignored, indicating that the total pressure in the headspace was constant during the dissolution.

$$
\begin{gathered}
\mathrm{V}_{\mathrm{HS}}^{\mathrm{CH}_{4}}+\mathrm{V}_{\text {water }}^{\mathrm{CH}_{4}}=\mathrm{V}_{\text {inj }}^{\mathrm{CH}_{4}}+\mathrm{V}_{\mathrm{HS}}^{\mathrm{CH}_{4}^{*}}+\mathrm{V}_{\text {water }}^{\mathrm{CH}_{4}^{*}} \\
\mathrm{~V}_{\text {water }}^{\mathrm{CH}_{4}}=\mathrm{C}_{\text {water }}^{\mathrm{CH}_{4}} \times \mathrm{V}_{\text {water }} \times \mathrm{V}_{\mathrm{m}}
\end{gathered}
$$

where $\mathrm{V}_{\mathrm{HS}}^{\mathrm{CH}_{4}^{*}}$ is the volume of $\mathrm{CH}_{4}$ in the headspace before injection $(\mathrm{L}), \mathrm{V}_{\text {water }}^{\mathrm{CH}_{4}^{*}}$ is the volume of $\mathrm{CH}_{4}$ in the water before injection ( $\left.\mathrm{L}\right), \mathrm{V}_{\mathrm{HS}}^{\mathrm{CH}_{4}^{*}}$ is measured using $\mathrm{GC}$, and $\mathrm{V}_{\text {water }}^{\mathrm{CH}_{4}^{*}}$ is measured according to Equation (8):

$$
\mathrm{C}_{\text {water }}^{\mathrm{CH}_{4}}=\frac{\mathrm{P} \times \mathrm{H} \times\left(\mathrm{V}_{\mathrm{inj}}^{\mathrm{CH}_{4}}+\mathrm{V}_{\mathrm{HS}}^{\mathrm{CH}_{4}^{*}}+\mathrm{V}_{\text {water }}^{\mathrm{CH}_{4}^{*}}\right) \times\left(\mathrm{V}_{\text {inj }}^{\mathrm{CH}_{4}}+\mathrm{V}_{\mathrm{HS}}\right)}{\mathrm{V}_{\mathrm{HS}}^{2}+\mathrm{P} \times \mathrm{H} \times \mathrm{V}_{\text {water }} \times \mathrm{V}_{\mathrm{m}} \times\left(\mathrm{V}_{\text {inj }}^{\mathrm{CH}_{4}}+\mathrm{V}_{\mathrm{HS}}\right)}
$$

\subsubsection{Determination Range}

We reviewed the concentrations of dissolved $\mathrm{CH}_{4}$ in various natural waters. It can be seen from Table 1 that the concentrations of $\mathrm{CH}_{4}$ in the natural water column were in the order of nanomolar to micromolar, which required our instrument to have a low detection limit. Therefore, the concentration of the $\mathrm{CH}_{4}$ standard sample we prepared was within this range. Here, we configured eight $\mathrm{CH}_{4}$ standard samples with different concentrations ranging from $2.63-593.93 \mathrm{nmol} \mathrm{L}^{-1}$ because previous studies showed that the concentration of $\mathrm{CH}_{4}$ in freshwater Lake Taihu ranged from 0 to $400 \mathrm{nmol} \mathrm{L}^{-1}$ [20].

Table 1. $\mathrm{CH}_{4}$ concentrations in different natural water bodies.

\begin{tabular}{ccccc}
\hline Water Bodies & Location & Type of Water & $\mathbf{C H}_{4}$ Concentration & Reference \\
\hline Lake Lugano & Switzerland-Italy & Water column & $0.1-80 \mu \mathrm{mol} \mathrm{L}^{-1}$ & {$[21]$} \\
Lake Onega & Russia & Water column & $0.116-5.45 \mu \mathrm{mol} \mathrm{L}^{-1}$ & {$[22]$} \\
130 lakes & Finland & Water column & $1-20.6 \mu \mathrm{mol} \mathrm{L}^{-1}$ & {$[23]$} \\
Coastal zone & Bight-Mexican sector & Surface water & $2.2-17.8 \mathrm{nmol} \mathrm{L}^{-1}$ & {$[24]$} \\
Paddy field & Italy & Porewater & $0.1-0.7 \mathrm{mmol} \mathrm{L}^{-1}$ & {$[25]$} \\
Rivers & China & Water column & $0.043-25.3 \mu \mathrm{mol} \mathrm{L}^{-1}$ & {$[26]$} \\
\hline
\end{tabular}

\subsubsection{Effect of Salinity on the Determination}

In order to demonstrate that our method was also applicable to saline aquatic ecosystems (such as oceans and saline lakes), we configured three $\mathrm{CH}_{4}$ standard samples with different salinities (0,15, and 30 respectively) [27], and established the $\mathrm{CH}_{4}$ standard curves with MIMS. The method of standard sample preparation was the same as described above. 
The concentration of dissolved $\mathrm{CH}_{4}$ in the standard sample was calculated according to Equation (8), where the specific concentrations are shown in Table 2.

Table 2. Concentrations of $\mathrm{CH}_{4}$ in standard samples $\left(\mathrm{T}=20^{\circ} \mathrm{C}\right)$.

\begin{tabular}{ccccccc}
\hline & \multicolumn{2}{c}{ Salinity $=\mathbf{0}$} & \multicolumn{2}{c}{ Salinity $=\mathbf{1 5}$} & \multicolumn{2}{c}{ Salinity $=\mathbf{3 0}$} \\
\hline Vial & $\mathbf{V}(\mu \mathrm{L})$ & $\mathbf{C}\left(\mu \mathbf{m o l ~ L} \mathbf{L}^{-1}\right)$ & $\mathbf{V}(\mu \mathrm{L})$ & $\mathbf{C}\left(\mu \mathbf{m o l ~ \mathbf { L } ^ { - 1 } )}\right.$ & $\mathbf{V}(\mu \mathbf{L})$ & $\mathbf{C}\left(\mu \mathbf{m o l ~ L} \mathbf{L}^{-1}\right)$ \\
\hline 1 & 0 & 0.003 & 0 & 0.002 & 0 & 0.002 \\
2 & 0.1 & 0.032 & 0.1 & 0.029 & 0.1 & 0.027 \\
3 & 0.2 & 0.062 & 0.2 & 0.056 & 0.2 & 0.052 \\
4 & 0.3 & 0.091 & 0.3 & 0.083 & 0.3 & 0.076 \\
5 & 0.4 & 0.121 & 0.4 & 0.110 & 0.4 & 0.101 \\
6 & 0.5 & 0.150 & 0.5 & 0.137 & 0.5 & 0.125 \\
7 & 1 & 0.298 & 1 & 0.272 & 1 & 0.249 \\
8 & 2 & 0.594 & 2 & 0.543 & 2 & 0.496 \\
\hline
\end{tabular}

Notes: $\mathrm{V}$ indicates the volume of $\mathrm{CH}_{4}$ added to each vial; $\mathrm{C}$ represents the dissolved $\mathrm{CH}_{4}$ concentration.

\subsection{Application to Lake Taihu}

\subsubsection{Study Sites}

Lake Taihu, which is one of the five largest freshwater lakes in China, is the largest lake in Jiangsu Province (Figure 2a). The southern edge of the lake area is located on the boundary line between Jiangsu and Zhejiang provinces, with a lake area of $2340 \mathrm{~km}^{2}$. The annual average water depth is about $2 \mathrm{~m}$, and the lake volume is 4.4 billion cubic meters [28] Lake Taihu is located in a subtropical zone. The air temperature fluctuates between 3 and $37^{\circ} \mathrm{C}$. The annual average air temperature is $16.0-18.0^{\circ} \mathrm{C}$, and the annual precipitation is $1100-1150 \mathrm{~mm}$. Farmland is the main land-use form surrounding Lake Taihu, accounting for $32.0 \%$, followed by forest land, urban areas, and reservoirs and ponds, accounting for $27.6 \%, 18.7 \%$, and $14.3 \%$, respectively. The eutrophication of Lake Taihu was aggravated by human-induced nutrient loading. Due to the high degree of eutrophication in Lake Taihu, cyanobacteria have often bloomed during summer in recent years, which seriously affects the water quality [28-32]. Lake Taihu is a sink for nutrients and organic carbon [33] and is a large shallow lake with complex ecological types, including a planktonic algae zone (e.g., Dapu) (Figure 2d), aquatic plant zone (e.g., Xukou) (Figure 2c), and aquatic plant-algae transitional zone (e.g., Gonghu) [28]. These differences lead to the great spatial distribution of water quality and sediment properties. A recent study showed that there were also significant differences in $\mathrm{CH}_{4}$ emissions from different regions of Lake Taihu. The $\mathrm{CH}_{4}$ emissions in the algal and aquatic plant areas were significantly higher than that in other lake areas, and the $\mathrm{CH}_{4}$ emission flux can reach $0.54 \pm 0.30 \mathrm{~g} \mathrm{C} \mathrm{m}^{-2} \mathrm{yr}^{-1}$, which was seriously underestimated [8]. Thus, we took Lake Taihu as the study site and investigated the $\mathrm{CH}_{4}$ concentration of surface water at 29 sites in all lake areas (Figure 2b). These 29 sampling sites were distributed evenly across the whole lake based on the lake area. The aim was to observe the differences between these areas and to evaluate the advantages and disadvantages of MIMS and GC in the measurement of dissolved $\mathrm{CH}_{4}$. In order to evaluate the method of MIMS regarding determining the $\mathrm{CH}_{4}$ production capacities of sediments, we selected three different types of lake areas, namely, Dapu, Gonghu, and Xukou Bay, and collected undisturbed sediment columns at sites 9,12 , and 25 for laboratory experiments. 

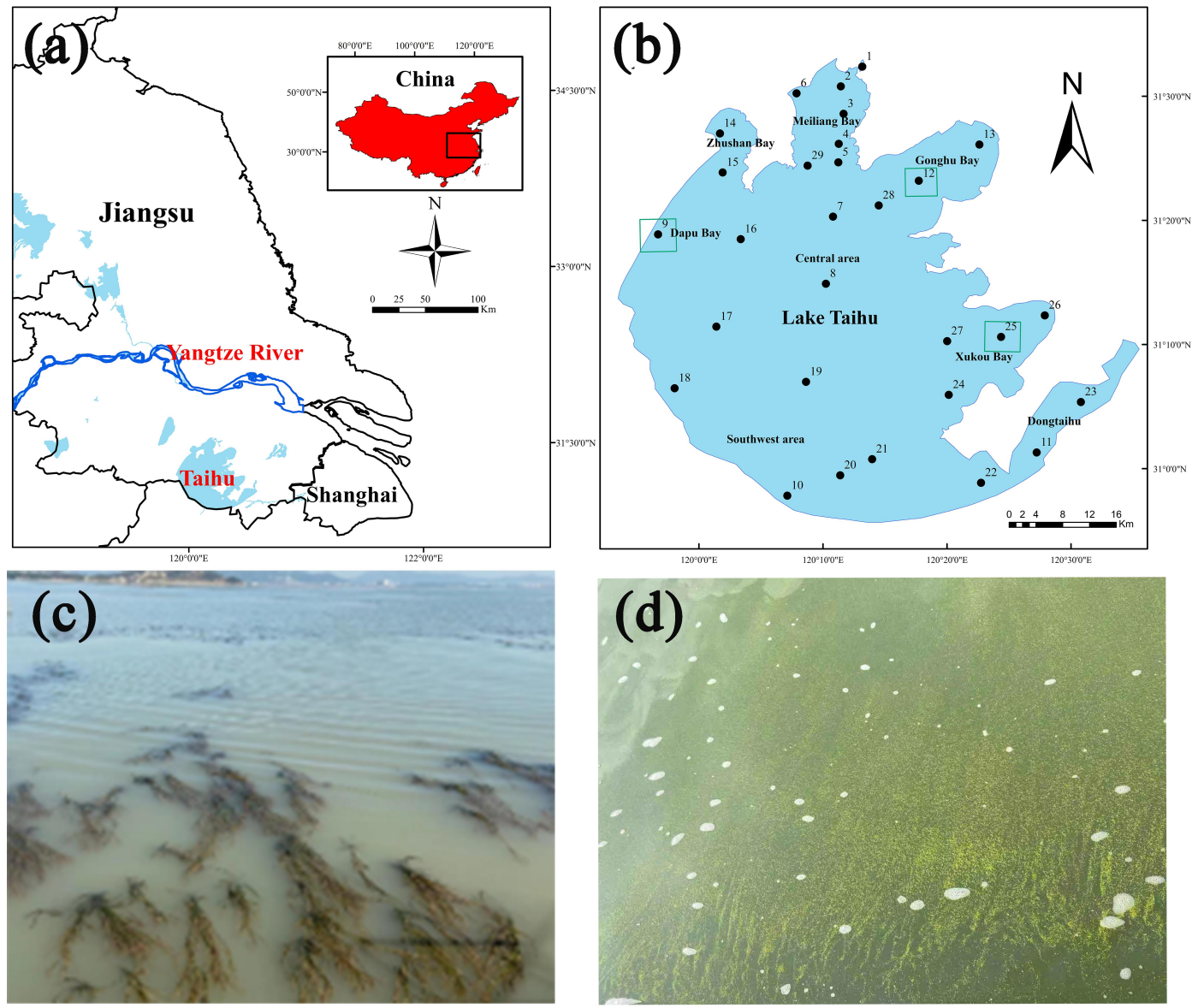

Figure 2. (a) The location of Lake Taihu in Jiangsu Province; (b) the specific distribution of sampling sites in Lake Taihu, where the black spots are 29 sites for surface gas collection and the green square frames are 3 points for collecting sediments; (c,d) images of an aquatic-plant-covered area and an algal-covered area, respectively.

\subsubsection{Method for Sampling and Data Acquisition}

The samples that were used for measuring $\mathrm{CH}_{4}$ concentrations based on the MIMS method needed to be preserved under non-headspace conditions. Therefore, we collected water samples from a depth about $20 \mathrm{~cm}$ below the water surface because directly collecting samples from surface water may sample the ambient air and further affect the subsequent measurement. To compare with the MIMS method, the samples used for determining the $\mathrm{CH}_{4}$ concentrations based on the HGC method were also collected at the same depth, which was different from the traditional method that directly collected water samples at the water-air interface. The samples that were used for measuring $\mathrm{CH}_{4}$ concentrations based on the MIMS method were immediately supplemented with $100 \mu \mathrm{L}$ saturated $\mathrm{ZnCl}_{2}$ solution to inhibit microbial activity. Samples for the measurement of $\mathrm{CH}_{4}$ concentration using the HGC method were prepared via equilibration with ambient air. Briefly, $400 \mathrm{~mL}$ surface water and $100 \mathrm{~mL}$ ambient air were sampled using a 2-way stopcock valve. With the valves closed, the bottle was shaken vigorously for about $5 \mathrm{~min}$ to reach equilibrium. The headspace was transferred to a serum bottle that was filled with saturated $\mathrm{NaCl}$ solution using two needles [34]. The gas samples were determined using a GC (Model Agilent GC6890N, Agilent Co., CA, USA) that was equipped with a flame ionization detector. It should be noted that the ambient air should be measured to adjust the dissolved gas headspace samples when comparing this method with the MIMS method. However, the ideal dissolved $\mathrm{CH}_{4}$ concentration after balancing with the air above the surface water is very low (e.g., $3 \mathrm{nmol} \mathrm{L}-1$ under $1.7 \mathrm{ppm}$ in freshwaters in $20^{\circ} \mathrm{C}$ ). Therefore, for waters with high $\mathrm{CH}_{4}$ concentrations (e.g., Lake Taihu), the dissolved $\mathrm{CH}_{4}$ in the water column was 
primarily from sediments and its self-production in water rather than from the atmosphere, indicating that the $\mathrm{CH}_{4}$ in the ambient air had little effect on the comparison between the MIMS method and the HGC method if we selected Lake Taihu (a large shallow lake with high $\mathrm{CH}_{4}$ concentrations) as the sampling area. The water temperature at the sampling sites was measured using a multi-sensor probe (YSI $6600 \mathrm{~V} 2)$.

\subsubsection{Incubation Experiment for Sediment $\mathrm{CH}_{4}$ Production Rate}

$\mathrm{CH}_{4}$ production rates from sediments were determined via incubation. A large sediment core was used to determine the denitrification and anammox rates based on the continuous flow-through method [35] in our previous studies [32]. Here, we also used a large core to collect sediment with the overlying water from the lake and then separated it into four smaller cores that were placed on the opposite end as the ejector pin (Figure 3). These smaller cores were used to quantify the $\mathrm{CH}_{4}$ flux at the sediment-water interface. The smaller cores were put into a constant temperature water bath where the temperature was set to the same as the lake water for incubation. Too long of an incubation time may lead to a decrease in the dissolved oxygen (DO) in the water column and may be unable to represent the in situ conditions; therefore, the incubation time was set at 2 days. The concentrations of $\mathrm{CH}_{4}$ and DO were measured pre-incubation and post-incubation, respectively. Triplicate incubation experiments were conducted at the three sampling sites.
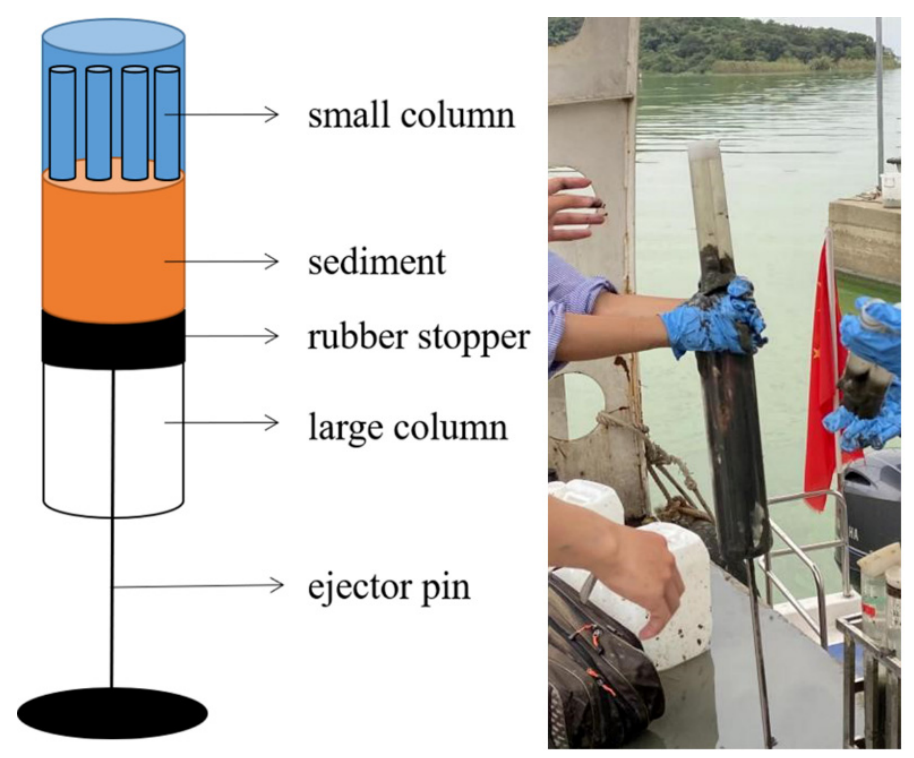

Figure 3. Schematic diagram of the sampling device.

\subsubsection{Calculation of $\mathrm{CH}_{4}$ Production Rates}

The $\mathrm{CH}_{4}$ production rate was calculated using the concentration difference between post-incubation and pre-incubation. The calculation formula was as follows:

$$
\mathrm{R}=\left(\mathrm{C}-\mathrm{C}_{0}\right) \times \mathrm{V} / \mathrm{S} / \mathrm{T}
$$

where $\mathrm{R}$ is the $\mathrm{CH}_{4}$ production rate $\left(\mu \mathrm{mol} \mathrm{m}{ }^{-2} \mathrm{~d}^{-1}\right), \mathrm{C}_{0}$ is the initial $\mathrm{CH}_{4}$ concentration $(\mu \mathrm{mol}$ $\left.\mathrm{L}^{-1}\right), \mathrm{C}$ is the $\mathrm{CH}_{4}$ concentration after incubation $\left(\mu \mathrm{mol} \mathrm{L}^{-1}\right), \mathrm{V}$ is the headspace volume $(\mathrm{L}), \mathrm{S}$ is the basal area of the incubation column $\left(\mathrm{m}^{2}\right)$, and $\mathrm{T}$ is the incubation time (day).

\subsection{Comparison with GC Method}

We used GC to measure the concentration of $\mathrm{CH}_{4}$ in the headspace to calculate the concentration of dissolved $\mathrm{CH}_{4}$ in the samples. The specific calculation formula was as follows:

$$
\mathrm{C}_{\text {water }}^{\mathrm{CH}_{4}}=\mathrm{C}_{\mathrm{HS}}^{\mathrm{CH}_{4}} \times\left(\mathrm{HRT}+\mathrm{V}_{\mathrm{HS}} / \mathrm{V}_{\text {water }}\right)
$$


where $\mathrm{C}_{\text {water }}^{\mathrm{CH}_{4}}$ represents the methane content in the water before equilibrium $\left(\mu \mathrm{mol} \mathrm{L}{ }^{-1}\right)$, $\mathrm{C}_{\mathrm{HS}}^{\mathrm{CH}_{4}}$ is the $\mathrm{CH}_{4}$ content in the headspace after equilibrium $\left(\mu \mathrm{mol} \mathrm{L}{ }^{-1}\right), \mathrm{H}$ is Henry's law constant $\left(\mathrm{mol}(\mathrm{L} \mathrm{atm})^{-1}\right), \mathrm{R}$ is the ideal gas constant $\left(\mathrm{L} \mathrm{atm}(\mathrm{mol} \mathrm{K})^{-1}\right), \mathrm{T}$ is the temperature $(\mathrm{K}), \mathrm{V}_{\mathrm{HS}}$ is the volume of headspace $(\mathrm{L})$, and $\mathrm{V}_{\text {water }}$ is the volume of water $(\mathrm{L})$.

\subsection{Statistical Analysis}

Linear regression was usually used to detect the relationship between two variables. Here, we used linear regression to show the relationship between the dissolved $\mathrm{CH}_{4}$ concentration and the $\mathrm{CH}_{4}$ signal value from MIMS to test whether the MIMS method was reliable. Linear regression was also used to investigate the relationship between dissolved $\mathrm{CH}_{4}$ concentrations derived from the two different methods. Furthermore, we used the $t$-test to show the differences in the dissolved $\mathrm{CH}_{4}$ concentrations derived from the two different methods. If the $p$-value was greater than 0.05 , it indicated no significant differences in the dissolved $\mathrm{CH}_{4}$ concentrations derived from the two different methods. The linear regression was performed using Origin 8.0, while the $t$-test was conducted using IBM SPSS 19.0. The figures were produced in Origin 8.0 and ArcGis 10.4.1.

\section{Results}

\subsection{Instrument Response to $\mathrm{CH}_{4}$ Standards}

The standard curves across a range of air saturation $(1.7 \mathrm{nM})$ to $800 \mu \mathrm{M}$ were highly linear $\left(R^{2}>0.999\right.$; Figure $\left.4 b\right)$. In addition, under three different salinities, the relationship (Figure 4a) between the $\mathrm{CH}_{4}$ concentration and signal value were very significant $\left(R^{2}=0.99813, p<0.0001\right.$ for $S=0 ; R^{2}=0.99733, p<0.0001$ for $S=15 ; R^{2}=0.99882, p<0.0001$ for $S=30$ ), indicating that salinity had little effect on the accuracy of standard curves.
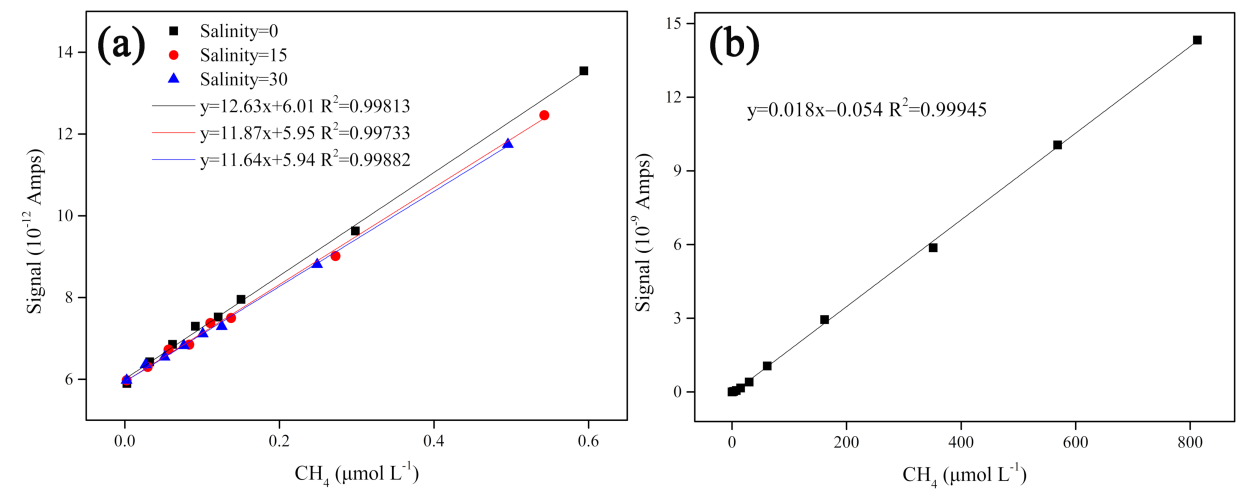

Figure 4. (a) Fitting curves using the $\mathrm{CH}_{4}$ concentration as the abscissa and signal values as the ordinate under different salinities $(0,15$, and 30$)$ at $20^{\circ} \mathrm{C}$. The black, red, and blue curves represent the fitting curves at salinities of 0,15 , and 30, respectively. (b) Fitting curve for high $\mathrm{CH}_{4}$ concentrations of standard samples at $20^{\circ} \mathrm{C}$.

\subsection{Comparison of the MIMS and HGC Methods}

In order to determine whether MIMS was reliable, we compared the results with HGC measurements. We selected 29 sites in Lake Taihu and determined the concentration of $\mathrm{CH}_{4}$ in the surface water using HGC and MIMS. As shown in Figure 5a, the spatial distribution of $\mathrm{CH}_{4}$ concentrations in the surface water of Lake Taihu was greatly significant, ranging from 0.02 to $0.70 \mu \mathrm{mol} \mathrm{L}^{-1}$ based on the MIMS method. As a whole, the values obtained from MIMS were consistent with those from HGC, and the linear relationship was also very significant (Figure $5 b$ ). Interestingly, we observed that the slope of the fitting curve was greater than 1 and the $\mathrm{CH}_{4}$ concentrations derived from the MIMS method in many sampling sites were a bit higher than those derived from the HGC method; however, this difference was not significant according to the $t$-test $(p>0.05)$. 

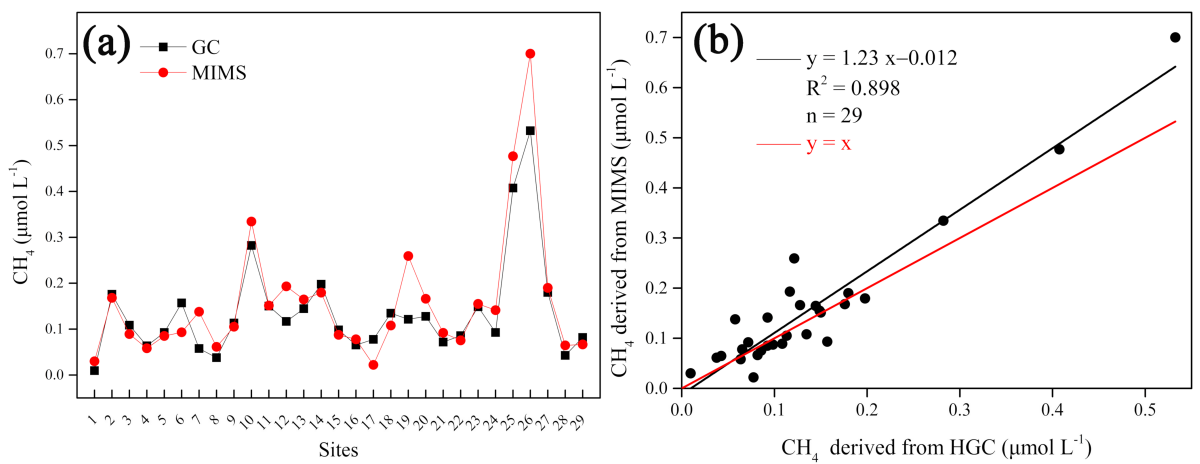

Figure 5. Relationship between the $\mathrm{CH}_{4}$ concentrations derived from MIMS and $\mathrm{CH}_{4}$ concentrations based on GC. (a) represents the differences between GC and MIMS, (b) is the fitting curve between GC and MIMS.

\section{3. $\mathrm{CH}_{4}$ Concentrations and Sediment $\mathrm{CH}_{4}$ Production Rates in Lake Taihu}

In Xukou Bay, the concentrations of $\mathrm{CH}_{4}$ in surface water were very high, where the highest value was more than $0.63 \mu \mathrm{mol} \mathrm{L}^{-1}$ (Figure 5a), but it was very low in the center of the lake, which was less than $0.1 \mu \mathrm{mol} \mathrm{L}{ }^{-1}$ in some sites. We used MIMS to determine the concentration of dissolved $\mathrm{CH}_{4}$ in a non-headspace incubation experiment, where the results are shown in Figure 6. The dissolved $\mathrm{CH}_{4}$ accumulations were observed in the cores of Xukou, Dapu, and Gonghu Bays (Figure 6a). The $\mathrm{CH}_{4}$ production rate in Xukou Bay was the highest, reaching $0.48 \pm 0.34 \mathrm{mmol} \mathrm{m}^{-2} \mathrm{~d}^{-1}$, followed by Gonghu and Dapu Bays, with the values of $0.19 \pm 0.04$ and $0.12 \pm 0.06 \mathrm{mmol} \mathrm{m}^{-2} \mathrm{~d}^{-1}$, respectively (Figure 6b). These results indicated that the $\mathrm{CH}_{4}$ production was obvious in these three sampling sites. Generally, no significant decrease in DO concentrations was observed during the incubation experiment.
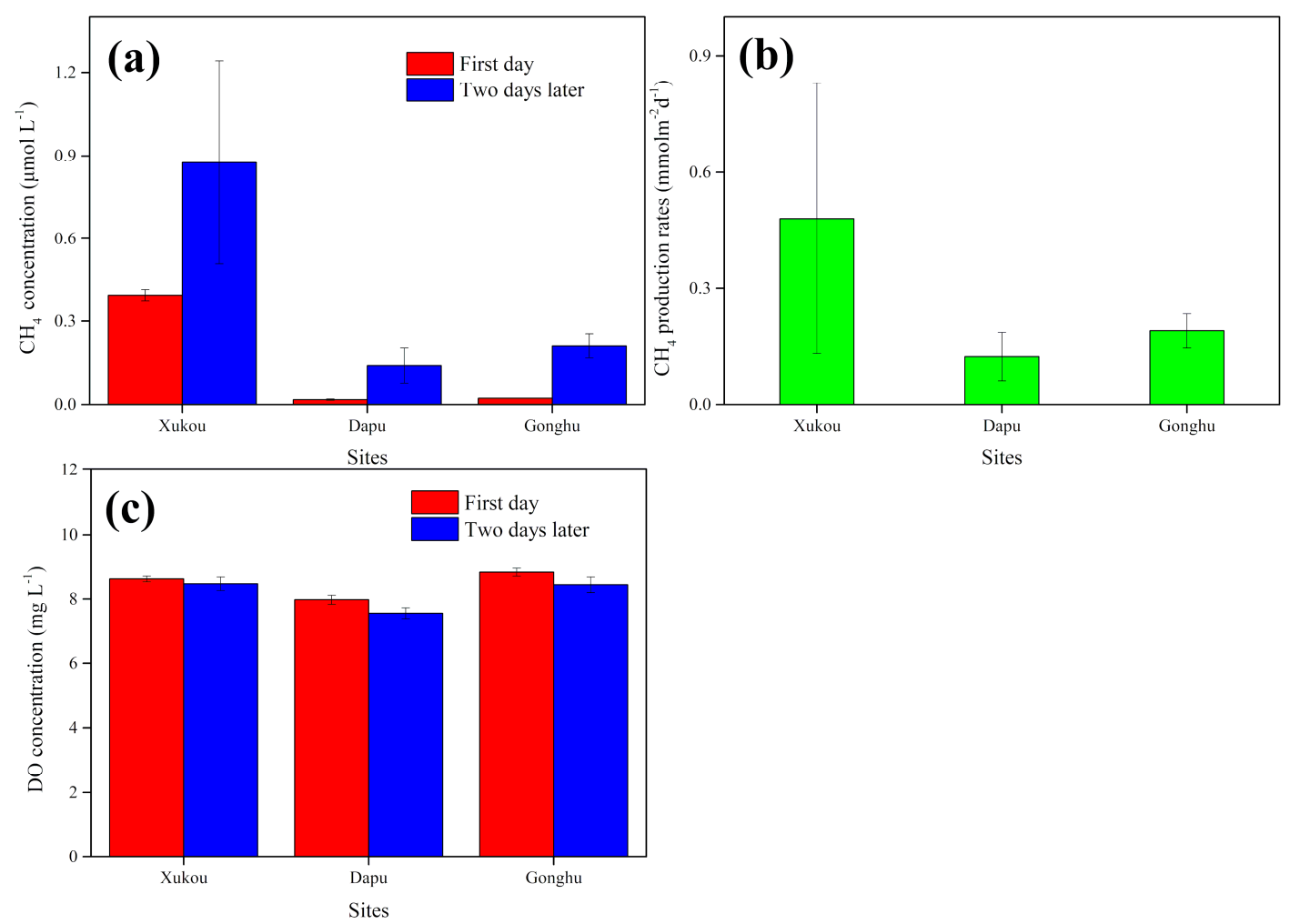

Figure 6. (a) The concentration of dissolved $\mathrm{CH}_{4}$ in the incubation experiment, where red means before incubation and blue means after incubation; (b) $\mathrm{CH}_{4}$ production rates of sediments; (c) the DO concentrations in the incubation experiment. 


\section{Discussion}

\subsection{Assessment of the Analytical Technique}

$\mathrm{CH}_{4}$ detection using MIMS has a 40-year history, where it has been primarily used for microbiological rate measurements under experimental conditions [12]. MIMS has not been the preferred method for environmental water samples; instead, the HGC method is commonplace. Notably, submersible MIMS is incorporated in ROVs for sniffing hydrocarbons in marine systems [36]. Here, we describe a MIMS method that is rapid, precise, sensitive, suited to both trace and highly concentrated samples, and suited to the environmental sampling of water bodies. Contributing to these characteristics is the configuration of the membrane interface. The MIMS used in this study constrains diffusion by imposing a laminar flow across the membrane and having good temperature control of the water flowing across the membrane. This results in sample replicate C.V.s of $0.2 \%$ for ion currents (proportional to concentration data) and $0.03 \%$ for gas ratios for air gases [14]. $\mathrm{CH}_{4}$ detection at mass 15 avoids interference from variable $\mathrm{O}_{2}$ in environmental water samples. However, depending on the mass spectrometer and its settings, there can be mass overlap across adjacent unit masses $[37,38]$. In the case of $\mathrm{CH}_{4}$, the mass spectrometer mass resolution may allow $\mathrm{O}^{+}$ions to be detected at mass 15 . This can have a significant effect that is observed as a correlation between mass 15 ion currents and oxygen concentration when measuring trace levels of $\mathrm{CH}_{4}$. The effect can be minimized or eliminated by reducing the resolution parameter of the quadrupole mass spectrometer. Mass 15 is the methyl ion that is also produced by the fragmentation of organic molecules that may pass through the membrane. The use of a liquid nitrogen cryotrap in this study effectively traps all organics that may otherwise interfere at mass 15 . Therefore, the mass 15 signal represents an unambiguous measure of $\mathrm{CH}_{4}$ using the MIMS configuration described here. We demonstrated linearity across low nanomolar to high micromolar concentrations spanning the range expected in nature, including systems experiencing $\mathrm{CH}_{4}$ ebullition.

\subsection{Comparison with HGC}

As shown in Figure $5 b$, the linear relationship between the dissolved $\mathrm{CH}_{4}$ concentrations derived from the two different methods was significant. However, there were still some small differences. We are confident in the MIMS method because of the satisfactory standard curves (Figure 4). Hence, we speculated that these small differences may have been caused by the potential errors in the HGC method. Headspace equilibration was used to prepare the standard samples for determining $\mathrm{CH}_{4}$ concentrations using the MIMS method. During the standard sample preparation, the vials were shaken for more than 5 min, which was the same as collecting water samples using the HGC method during the field sampling. The standard curves show that the $\mathrm{CH}_{4}$ signal values displayed very close relationships for various $\mathrm{CH}_{4}$ concentrations. Hence, we concluded that the small differences in $\mathrm{CH}_{4}$ concentrations may not have been caused by incomplete equilibration. Here, we speculated that this small difference may have been due to the following reasons: (1) In the traditional HGC method, the saturated $\mathrm{NaCl}$ solution was replaced by the headspace that was from the syringe after the equilibration with lake water. This process was conducted using two gas-tight syringes. However, the injection of the headspace into the serum bottle that was filled with saturated $\mathrm{NaCl}$ solution may have easily cause micro-bubbles. Such micro-bubbles may escape with the $\mathrm{NaCl}$ solution through another syringe, leading to an underestimate of the dissolved $\mathrm{CH}_{4}$ concentrations. Furthermore, the higher the $\mathrm{CH}_{4}$ in the headspace, the higher the underestimate of the dissolved $\mathrm{CH}_{4}$ concentration will be. (2) Some $\mathrm{CH}_{4}$ in the headspace may redissolve in the $\mathrm{NaCl}$ solution. For a high $\mathrm{CH}_{4}$ concentration in the headspace, the loss of $\mathrm{CH}_{4}$ in the headspace caused by redissolution is also high, which may be one of the important reasons for the higher dissolved $\mathrm{CH}_{4}$ obtained from the MIMS method under high $\mathrm{CH}_{4}$ concentrations. (3) The transfer of headspace from the syringe to the serum bottle should be conducted carefully. However, during the field samplings, there are too many factors that may affect the transfer, 
such as the shaking of the boat induced by lake waves due to a high wind speed. Such shaking often appears in large, shallow, and open waters (e.g., Lake Taihu).

In the MIMS method, in addition to the standard samples, the collected field samples do not need headspace processing, and the sampling device is very simple. Only a $12 \mathrm{~mL}$ water sample is needed at each site for determination, which means that we can take multiple samples for analysis to reduce the systematic error. It takes about $5 \mathrm{~min}$ to determine a sample using the HGC method, but less than 2 min for the MIMS method, which greatly improves the efficiency of sample determination. In addition, the MIMS method can simultaneously measure oxygen, nitrogen, and argon from the same sample vial, which saves a lot of time and labor costs. Furthermore, during the field sampling, the HGC method requires shaking the lake water with air for at least $5 \mathrm{~min}$, while using the MIMS method does not need to make a headspace during sampling and the sampling can be finished within $30 \mathrm{~s}$. For large waters, such as Lake Taihu, sampling from 29 sites across the whole lake using the MIMS method can be finished within half a day. However, it would take at least 2 days if we used the HGC methods. As is well known, the temporal change may lead to the variation in $\mathrm{CH}_{4}$ concentrations. Therefore, for those who want to collect numerous samples on a short-time scale or want to investigate the spatial distribution of $\mathrm{CH}_{4}$ concentrations in waters, the MIMS method is more preferred. Additionally, due to the rapid response of the MIMS signal to the variation in $\mathrm{CH}_{4}$ concentration, MIMS can be used for real-time monitoring of the concentration of $\mathrm{CH}_{4}$ if desired, which cannot be achieved using the HGC method. It should be noted that the MIMS method also has limitations. Compared with the HGC method, the MIMS method cannot be used to simultaneously determine the concentrations of dissolved carbon dioxide and nitrous oxide since these two gases have almost the same relative atomic mass ( 44$)$, which can not be distinguished using MIMS.

\subsection{Assessment of the MIMS Method in Lake Taihu}

The peak value of the $\mathrm{CH}_{4}$ concentration measured using the MIMS method appeared in Xukou Bay (Figure 5a), which may have been related to the large number of floating plants and submerged plants there. The degradation of aquatic plants will add a lot of organic carbon to the water and sediments, which is the substrate of $\mathrm{CH}_{4}$ production [39]. The incubation experiment indicated that Lake Taihu was an important source of $\mathrm{CH}_{4}$ in summer. A study has shown that submerged macrophytes can significantly promote $\mathrm{CH}_{4}$ emission from lakes. In our experiment, the $\mathrm{CH}_{4}$ production rate of sediments in Xukou Bay was the highest, which may be related to the large number of aquatic plants and submerged plants there. Evident $\mathrm{CH}_{4}$ accumulations also appeared in Dapu and Gonghu Bays. These two lake areas were covered with algae, and the presence of cyanobacteria could significantly promote $\mathrm{CH}_{4}$ production [40]. Here, we compared our results with those in previous studies, where the results are shown in Table 3. Our results were generally lower than those in previous studies, which may have been related to the different properties of sediments; however, the rate of $\mathrm{CH}_{4}$ release from sediments into the water column was still very high, suggesting that shallow waters (e.g., Lake Taihu) were hotspots for $\mathrm{CH}_{4}$ production and emission.

Table 3. $\mathrm{CH}_{4}$ productions from sediments in previous studies.

\begin{tabular}{ccccc}
\hline Location & Type & Method & $\mathbf{C H}_{\mathbf{4}}$ Production Rates & Reference \\
\hline Lake Izunuma & In sediment & Incubation, GC & $29.85 \mathrm{mmol} \mathrm{m}^{-2} \mathrm{~d}^{-1}$ & {$[41]$} \\
Lake Wintergreen & Water-sediment & In situ determination, GC & $10-46 \mathrm{mmol} \mathrm{m}^{-2} \mathrm{~d}^{-1}$ & {$[42]$} \\
Lake Constance & In sediment & Incubation, GC & $5-95 \mathrm{mmol} \mathrm{m}^{-2} \mathrm{~d}^{-1}$ & {$[43]$} \\
Lake Toolik & Water-sediment & Incubation, GC & $0.393 \mathrm{mmol} \mathrm{m}^{-2} \mathrm{~d}^{-1}$ & {$[44]$} \\
Marine basin & Water-sediment & Chamber, GC & $2.328 \mathrm{mmol} \mathrm{m}^{-2} \mathrm{~d}^{-1}$ & {$[45]$} \\
Our study: Lake Taihu & Water-sediment & Incubation, MIMS & $0.12-0.48 \mathrm{mmol} \mathrm{m}^{-2} \mathrm{~d}^{-1}$ & \\
\hline
\end{tabular}




\section{Conclusions}

In this study, we introduced a novel method based upon the MIMS method to determine the dissolved $\mathrm{CH}_{4}$ concentrations in natural waters. This method was tested in the laboratory and further applied to a large shallow lake, namely, Lake Taihu. Water samples, as well as sediment cores, were collected from Lake Taihu in the summer of 2020 to quantify the $\mathrm{CH}_{4}$ concentration and $\mathrm{CH}_{4}$ production rates based on the MIMS method. The results showed that Lake Taihu was an important source of $\mathrm{CH}_{4}$ in summer. Furthermore, a comparison between the MIMS method with the traditional method (HGC method) was also conducted. Laboratory tests and field sampling showed that our method had significant advantages when measuring dissolved $\mathrm{CH}_{4}$, including high precision, simple pretreatment, and a fast response. In addition, our method is not only suitable for freshwater lakes, but also other high salinity aquatic ecosystems, such as oceans and saline lakes. We are confident that our MIMS method can replace the traditional HGC method for the determination of dissolved $\mathrm{CH}_{4}$. Through our method, we could accurately quantify the water-air diffusive flux of $\mathrm{CH}_{4}$ and determine the $\mathrm{CH}_{4}$ release rate from sediments to the water column, which provides great convenience regarding studying the fate of $\mathrm{CH}_{4}$.

Author Contributions: Data curation, F.Z., X.Z. (Xu Zhan), W.Z., M.Z., L.K. and X.Z. (Xingchen Zhao); Formal analysis, F.Z.; Funding acquisition, H.X. and G.Z.; Investigation, F.Z.; Methodology, F.Z., H.X. and T.K.; Project administration, G.Z.; Writing-original draft, F.Z.; Writing-review and editing, H.X. and T.K. All authors have read and agreed to the published version of the manuscript.

Funding: This research was supported by the Strategic Priority Research Program of Chinese Academy of Sciences (XDA23040201) and the National Natural Science Foundation of China (41830757, 42077161).

Institutional Review Board Statement: Not applicable.

Informed Consent Statement: Not applicable.

Data Availability Statement: Not applicable.

Acknowledgments: We thank the three anonymous reviewers for their constructive comments for improving this manuscript.

Conflicts of Interest: Todd Kana owns Bay Instruments. The remaining authors declare that they have no known competing financial interests or personal relationships that could have appeared to influence the work reported in this paper.

\section{References}

1. Meinshausen, M.; Meinshausen, N.; Hare, W.; Raper, S.C.B.; Frieler, K.; Knutti, R.; Frame, D.J.; Allen, M.R. Greenhouse-gas emission targets for limiting global warming to $2{ }^{\circ} \mathrm{C}$. Nature 2009, 458, 1158-1162. [CrossRef] [PubMed]

2. Ramanathan, V.; Feng, Y. Air pollution, greenhouse gases and climate change: Global and regional perspectives. Atmos. Environ. 2009, 43, 37-50. [CrossRef]

3. Montzka, S.A.; Dlugokencky, E.J.; Butler, J.H. Non- $\mathrm{CO}_{2}$ greenhouse gases and climate change. Nature 2011, 476, 43-50. [CrossRef] [PubMed]

4. Pall, P.; Aina, T.; Stone, D.A.; Stott, P.A.; Nozawa, T.; Hilberts, A.G.J.; Lohmann, D.; Allen, M.R. Anthropogenic greenhouse gas contribution to flood risk in England and Wales in autumn 2000. Nature 2011, 470, 382-385. [CrossRef] [PubMed]

5. Yang, Z.; Grace, J.R.; Lim, C.J.; Zhang, L. Combustion of low-concentration coal bed methane in a fluidized bed. Energy Fuel 2011, 25, 975-980. [CrossRef]

6. Deborde, D.; Anschutz, P.; Guérin, F.; Poirier, D.; Marty, D.; Boucher, G.; Thouzeau, G.; Canton, M.; Abril, G.; Jonathan, D.; et al. Methane sources, sinks and fluxes in a temperate tidal Lagoon: The Arcachon lagoon (SW France). Estuar. Coast. Shelf Sci. 2010, 89, 256-266. [CrossRef]

7. Qin, X.; Li, Y.; Wan, Y.; Fan, M.; Liao, Y.; Li, Y.; Wang, B.; Gao, Q. Diffusive flux of $\mathrm{CH}_{4}$ and $\mathrm{N}_{2} \mathrm{O}$ from agricultural river networks: Regression tree and importance analysis. Sci. Total Environ. 2020, 717, 137244. [CrossRef]

8. Xiao, Q.; Zhang, M.; Hu, Z.; Gao, Y.; Hu, C.; Liu, C.; Liu, S.; Zhang, Z.; Zhao, J.; Xiao, W.; et al. Spatial variations of methane emission in a large shallow eutrophic lake in subtropical climate. J. Geophys. Res.-Biogeosci. 2017, 122, 1597-1614. [CrossRef]

9. Lomond, J.S.; Tong, A.Z. Rapid analysis of dissolved methane, ethylene, acetylene and ethane s.ing partition coefficients and headspace-gas chromatography. J. Chromatogr. Sci. 2011, 49, 469-475. [CrossRef] 
10. Villa, J.A.; Smith, G.J.; Ju, Y.; Renteria, L.; Angle, J.C.; Arntzen, E.; Harding, S.F.; Ren, H.; Chen, X.; Sawyer, A.H.; et al. Methane 445 and nitrous oxide porewater concentrations and surface fluxes of a regulated river. Sci. Total Environ. 2020, 715, 136920. [CrossRef]

11. Smith, R.L.; Böhlke, J.K. Methane and nitrous oxide temporal and spatial variability in two U.S. Midwestern streams containing high nitrate concentrations. Sci. Total Environ. 2019, 685, 574-588. [CrossRef]

12. Carlsen, H.N.; Joergensen, L.; Degn, H. Inhibition by ammonia of methane utilization in Methylococcus capsulatus (Bath). Appl. Microbiol. Biotechnol. 1991, 35, 124-127. [CrossRef]

13. Lauritsen, F.R.; Kotiaho, T. Advances in membrane inlet mass spectrometry (MIMS). Rev. Anal. Chem. 1996, 15, 237-264. [CrossRef]

14. Kana, T.M.; Darkangelo, C.; Hunt, M.D.; Oldham, J.B.; Bennett, G.E.; Cornwell, J.C. Membrane inlet mass spectrometer for rapid high-precision determination of $\mathrm{N}_{2}, \mathrm{O}_{2}$, and $\mathrm{Ar}$ in environmental water samples. Anal. Chem. 1994, 66, 4166-4170. [CrossRef]

15. Hou, L.; Yin, G.; Liu, M.; Zhou, J.; Zheng, Y.; Gao, J.; Zong, H.; Yang, Y.; Gao, L.; Tong, C. Effects of sulfamethazine on denitrification and the associated $\mathrm{N}_{2} \mathrm{O}$ release in estuarine and coastal sediments. Environ. Sci. Technol. 2014, 49, 326-333. [CrossRef] [PubMed]

16. Zhao, Y.; Xia, Y.; Ti, C.; Shan, J.; Li, B.; Xia, L.; Yan, X. Nitrogen removal capacity of the river network in a high nitrogen loading region. Environ. Sci. Technol. 2015, 49, 1427-1435. [CrossRef] [PubMed]

17. Bižić, M.; Klintzsch, T.; Ionescu, D.; Hindiyeh, M.Y.; Günthel, M.; Muro-Pastor, A.M.; Eckert, W.; Eckert, T.; Keppler, F.; Keppler, H.P. Aquatic and terrestrial cyanobacteria produce methane. Sci. Adv. 2020, 6, 5343. [CrossRef]

18. Kana, T.M.; Weiss, D.L. Comment on "Comparison of Isotope Pairing and $\mathrm{N}_{2}$ :Ar Methods for Measuring Sediment Denitrification" By B. D. Eyre, S. Rysgaard, T. Dalsgaard, and P. Bondo Christensen. 2002. Estuaries 25:1077-1087. Estuaries 2004, 25, 173-176. [CrossRef]

19. Wanninkhof, R. Relationship between wind speed and gas exchange over the ocean revisited. J. Geophys. Res. Ocean. 1992, 97, 7373-7382. [CrossRef]

20. Zhou, Y.; Xiao, Q.; Yao, X.; Zhang, Y.; Zhang, M.; Shi, K.; Lee, X.; David, C.P.; Qin, B.; Robert, G.M.S.; et al. Accumulation of terrestrial dissolved organic matter potentially enhances dissolved methane levels in eutrophic Lake Taihu, China. Environ. Sci. Technol. 2018, 52, 10297-10306. [CrossRef]

21. Liu, R.M.; Annette, H.; Fazil, O.G.; Pierre, Y.F.; Janusz, D. Methane concentration profiles in a lake with a permanently anoxic hypolimnion (Lake Lugano, Switzerland-Italy). Chem. Geol. 1996, 133, 201-209. [CrossRef]

22. Gar'kusha, D.N.; Fedorov, Y.A. Distribution of methane concentration in coastal areas of the Gulf of Petrozavodsk, Lake Onega. Water Resour. 2015, 42, 331-339. [CrossRef]

23. Juutinen, S.; Rantakari, M.; Kortelainen, P.; Huttunen, J.T.; Larmola, T.; Alm, J.; Martikainen, P.J. Methane dynamics in different boreal lake types. Biogeosciences 2009, 6, 209-223. [CrossRef]

24. Castro-Morales, K.; Macías-Zamora, J.V.; Canino-Herrera, S.R.; Burke, R.A. Dissolved methane concentration and flux in the coastal zone of the Southern California Bight-Mexican sector: Possible influence of wastewater. Estuar. Coast. Shelf Sci. 2014, 144, 65-74. [CrossRef]

25. Gilbert, B.; Frenzel, P. Methanotrophic bacteria in the rhizosphere of rice microcosms and their effect on porewater methane concentration and methane emission. Biol. Fertil. Soils 1995, 20, 93-100. [CrossRef]

26. Tan, Y.; Wang, D.; Deng, H.; Li, Y.; Yu, Z.; Chen, Z. Methane and nitrous oxide dissolved concentration and emission flux of plain river network in winter. Sci. Sin. Chim. 2013, 43, 919-929.

27. Yin, G.; Hou, L.; Liu, M.; Liu, Z.; Gardner, W.S. A novel membrane inlet mass spectrometer method to measure ${ }^{15} \mathrm{NH}_{4}{ }^{+}$for isotope-enrichment experiments in aquatic ecosystems. Environ. Sci. Technol. 2014, 48, 9555-9562. [CrossRef]

28. Qin, B.; Xu, P.; Wu, Q.; Luo, L.; Zhang, Y. Environmental issues of Lake Taihu, China. Hydrobiologia 2007, 581, 3-14. [CrossRef]

29. Qin, B.; Zhu, G.; Gao, G.; Zhang, Y.; Li, W.; Paerl, H.W.; Carmichael, W.W. A drinking water crisis in Lake Taihu, China: Linkage to climatic variability and lake management. Environ. Manag. 2011, 45, 105-112. [CrossRef] [PubMed]

30. Hu, C.; Lee, Z.; Ma, R.; Yu, K.; Li, D.; Shang, S. Moderate resolution imaging spectroradiometer (MODIS) observations of cyanobacteria blooms in Taihu Lake, China. J. Geophys. Res.-Ocean. 2010, 115, C04002. [CrossRef]

31. Zhao, F.; Zhan, X.; Xu, H.; Zhu, G.; Zou, W.; Zhu, M.; Kang, L.; Guo, Y.; Zhao, X.; Wang, Z.; et al. New insights into eutrophication management: Importance of temperature and water residence time. J. Environ. Sci. 2022, 111, 229-239. [CrossRef]

32. Zhao, F.; Xu, H.; Zhan, X.; Zhu, G.; Guo, Y.; Kang, L.; Zhu, M. Spatial differences and influencing factors of denitrification and ANAMMOX rates in spring and summer in Lake Taihu. Environ. Sci. 2021. [CrossRef]

33. Zhou, Y.; Yao, X.; Zhang, Y.; Zhang, Y.; Shi, K.; Tang, X.; Qin, B.; Podgorski, D.C.; Brookes, J.D.; Jeppesen, E. Response of dissolved organic matter optical properties to net inflow runoff in a large fluvial plain lake and the connecting channels. Sci. Total Environ. 2018, 639, 876-887. [CrossRef] [PubMed]

34. Donis, D.; Flury, S.; Stöckli, A.; Spangenberg, J.E.; Vachon, D.; McGinnis, D.F. Full-scale evaluation of methane production under oxic conditions in a mesotrophic lake. Nat. Commun. 2017, 8, 1-12. [CrossRef] [PubMed]

35. Risgaard-Petersen, N.; Nielsen, L.P.; Blackburn, T.H. Simultaneous measurement of benthic denitrification, with the isotope pairing technology and the $\mathrm{N}_{2}$ flux method in a continuous flow-through system. Water Res. 1998, 32, 3371-3377. [CrossRef] 
36. Mcmutrtry, G.M.; Wiltshire, J.C.; Bossuyt, A. Hydrocarbon seep monitoring using in situ deep sea mass spectrometry. In Europe Oceans; IEEE: Piscataway, NJ, USA, 2005.

37. Eyre, B.D.; Rysgaard, S.; Dalsgaard, T.; Christensen, P.B. Comparison of isotope pairing and $\mathrm{N}_{2}$ : Ar methods for measuring sediment denitrification-Assumptions, modifications, and implications. Estuaries 2020, 25, 1077-1087. [CrossRef]

38. Lunstrum, A.; Aoki, L.R. Oxygen interference with membrane inlet mass spectrometry may overestimate denitrification rates calculated with the isotope pairing technique. Limnol. Oceangr. Methods 2016, 14, 425-431. [CrossRef]

39. Horruitiner, C.D.; Varner, R.K.; Palace, M.W.; Johnson, J.E.; Wik, M.; Lungren, D.J. Examining the Role of Aquatic Vegetation in Methane Production: Examples from a Shallow High Latitude Lake in Abisko, Sweden. Available online: https: / agu.confex. $\mathrm{com} / \mathrm{agu} / \mathrm{fm} 15 /$ webprogram/Paper83308.html (accessed on 26 September 2021).

40. William, E.W.; James, J.C.; Stuart, E.J. Effects of algal and terrestrial carbon on methane production rates and methanogen community structure in a temperate lake sediment. Freshw. Biol. 2012, 57, 949-955.

41. Lay, J.; Miyahara, T.; Noike, T. Methane release rate and methanogenic bacterial populations in lake sediments. Water Res. 1996, 30, 901-908. [CrossRef]

42. Strayer, R.F.; Tiedje, J.M. In situ methane production in a small, hypereutrophic, hard-water lakes: Loss of methane from sediments by vertical diffusion and ebullition. Limnol. Oceanogr. 1978, 23, 1201-1206. [CrossRef]

43. Thebrath, B.; Rothfuss, F.; Whiticar, M.J.; Conrad, R. Methane production in littoral sediment of Lake Constance. FEMS Microbiol. Ecol. 1993, 102, 279-289. [CrossRef]

44. Gentzel, T.; Hershey, A.E.; Rublee, P.A.; Whalen, S.C. Net sediment production of methane, distribution of methanogens and methane-oxidizing bacteria, and utilization of methane-derived carbon in an arctic lake. Inland Waters 2012, 2, 77-88. [CrossRef]

45. Martens, C.S.; Klump, J.V. Biogeochemical cycling in an organic-rich coastal marine basin-I. Methane sediment-water exchange processes. Geochim. Cosmochim. Acta 1980, 44, 471-536. [CrossRef] 